\title{
上顎洞破壊型アスペルギルス症例
}

\author{
石光亮太郎・卜部 晋平・片岡 真吾 \\ 岩元 純一・佐野 啓介・川内 秀之
}

\section{Invasive Aspergillosis of the Maxillary Sinus}

\author{
Ryotaro Ishimitsu, Shinpei Urabe, Shingo Kataoka, \\ Junichi Iwamoto, Keisuke Sano and Hideyuki Kawauchi \\ (Shimane Medical School)
}

\begin{abstract}
We report a case of invasive aspergillosis of the maxillary sinus. A man, aged 84, complained of a headache and right visual disturbance. Radiographs and CT scans revealed opacification of the right maxillary sinus and destruction of the posterolateral bony wall.

The clinical diagnosis was optic neuropathy due to sinusitis. External antrotomy of the maxillary sinus and a transnasal ethmoidectomy was performed. Tyroid matter in the right maxillary sinus was subsequently shown to be aspergillus by histopathological examination. Aspergillus infection was accompanied by partial destruction of the posterolateral bony wall of the maxillary sinus.

Following surgery, fluconazole therapy was initiated and the patient responded relatively well. However, 2 months postoperatively, right temporalgia and unconsciousness gradually recurred. Three months postoperatively, the patient died due to sudden respiratory arrest.
\end{abstract}

Key words : invasive aspergillosis, maxillary sinus, visual disturbance, destruction of the posterolateral bony wall, aspergillus

はじめに

鼻副鼻腔真菌症は本邦に拈いても年々報告が増加して いるが1) 4)，その多くは症状の少ない寄生型であり，比 較的予後のよい疾患として従来取り扱われてきた。しか し，骨破壊を伴い，頭蓋内，眼窩内合併症を抗こしやす い破壊型のアスペルギルス症は予後が悪く，国内での報 告数も16例と比較的まれであるとされている. 今回我々 は視力障害を主訴に受診し, 上䫇洞開放術施行し, 病理 組織学検查によりアスペルギルス症と診断された破壊型 の上顎洞アスペルギルス症を経験したので報告する.

\section{症例}

患者: 84歳, 男性.

主訴 : 右視力障害.
既往歴 : 糖尿病.

現病歴: 平成 8 年 2 月 10 日, 右側頭部痛を自覚し, 3 日後に右の眼瞼下垂, 全外眼筋麻疩, 眼球突出が出現し たため， 2 月 16 日『眼窩先端症候群』の診断の下, 当院 眼科へ入院となった。 2 月 19 日, 突然の右視力低下と共 に右頓部腫脹, 右眼球突出も顕著となったため『鼻性眼 窩蜂窩織炎』の疑いで当科へ紹介転科となった.

入院時所見 : 胸部 X線, 心電図には特記すべき所見を 認めなかった。血液検査では CRP 陽性 $(3.7 \mathrm{mg} / \mathrm{dl})$, 血沈 $118 \mathrm{~mm}$ ( 1 時間值) と急性炎症の像を呈していた. ッベルクリン反応は陰性であった. 血清中の免疫グロブ リンは IgG $1200 \mathrm{mg} / \mathrm{dl}, \quad \operatorname{IgM} 106 \mathrm{mg} / \mathrm{dl}, \operatorname{IgA} 136 \mathrm{mg} /$ $\mathrm{dl}, \operatorname{IgE} 0.043 \mathrm{mg} / \mathrm{dl}$ と正常範囲であった. 末梢血血液 像, 末梢血の $\mathrm{B}$ 細胞百分率, $\mathrm{T}$ 細胞百分率 (ヘルパー, 
サプッレッサー百分率), 細胞性免疫検查 (リンパ球幼若 化検查) 特いては異常所見を認めなかった．生化学的 検查に括いて空腹時の血糖值が $230 \mathrm{mg} / \mathrm{dl}$ 之耐糖能異 常を示した。尿糖は陰性であった，神経学的には，視神 経, 眼球運動系の脳神経障害を認めるの久で，中枢症状 は認めなかった。眼球突出度は右 $19 \mathrm{~mm}$, 左 $15 \mathrm{~mm}$ で $4 \mathrm{~mm}$ の右眼球突出を認めた。右眼球運動は全方向で制

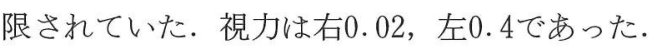

CT 所見: 右上顎洞内は低吸収像で, 点状飞高吸収像 を認めた。上顎洞後壁の後方，翼突窩に低吸収領域を認 め，後壁の骨欠損が疑われた，上顎洞前壁，内側壁は健 側に比し肥厚像を示した．篩骨洞，前頭洞には異常所見 認められなかった。眼窩内には明らかな異常陰影は認め なかった(図 1 )。

MRI 所見：T2 強調画像で，右上顎洞の後方，側頭下 窩から翼口蓋窩にかけて低信号領域を認めた。冠状断の $\mathrm{Gd}$ 造影画像では上顎洞の後方より眼窩先端部に連続す る高信号域を認めた(図 2 ).

以上の検查所見より，細菌性あるいは真菌性の上顎洞 炎，眼窩蜂窩織炎疑い，2 月19日，右上顎洞を開放した。

手術所見：上顎洞前壁㴘破壊は認めなかった。洞内 には黒褐色脆弱な内容物が充満して物り洞粘膜は一様に

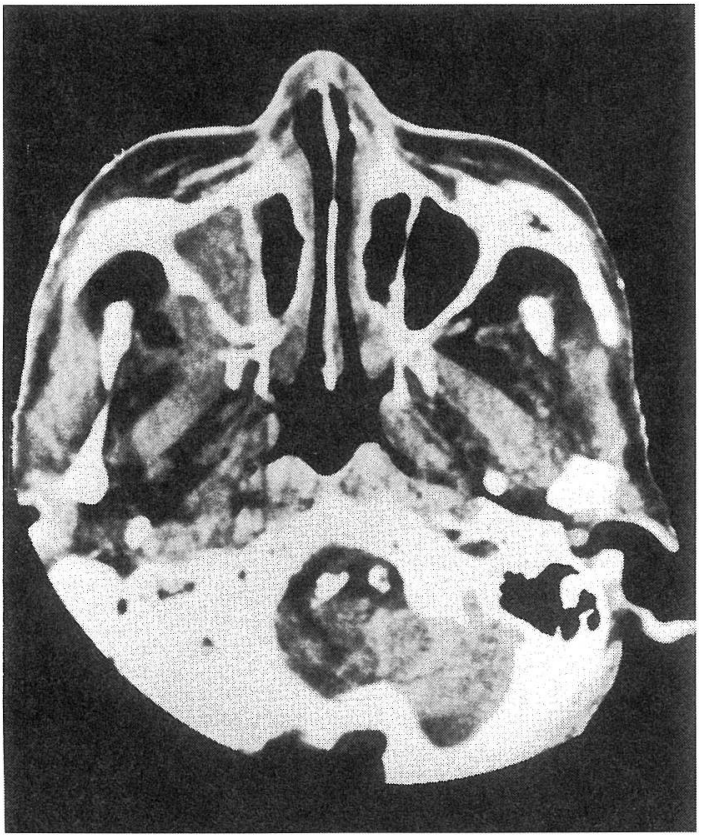

図 1 平成 8 年 2 月 16 日の CT 撮影像

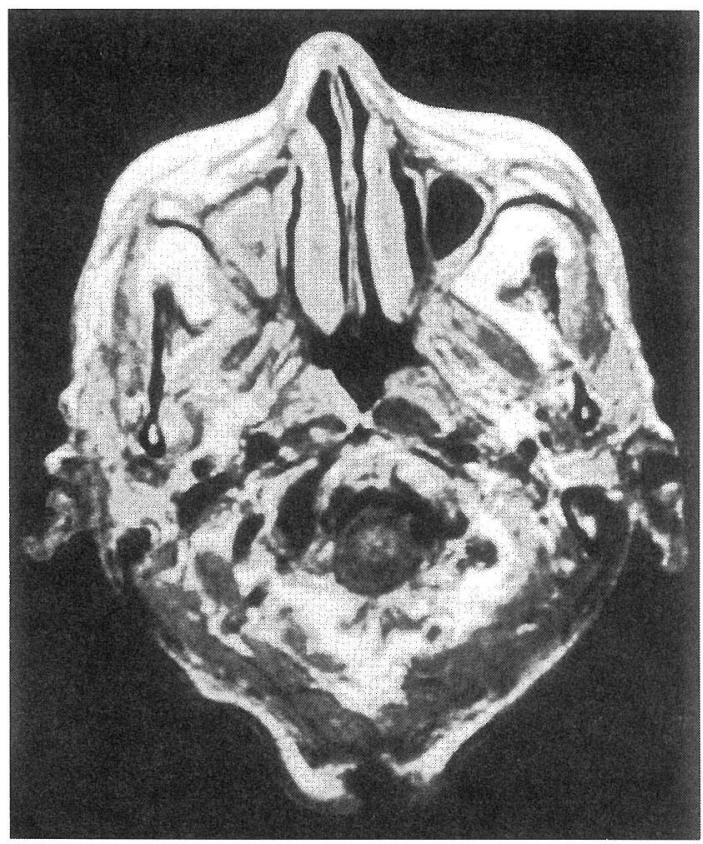

図 2 平成 8 年 2 月 19 日の $\mathrm{MRI}$ 撮影像 $\mathrm{T} 1$ 強調 $(\mathrm{Gd})$

線維性に肥厚していた．洞粘膜とともに内容物を搔爬し たところ上顎洞後壁に $2 \times 3 \mathrm{~mm}$ 大の骨欠損を認めた。

CT にて低吸収像を認めた，上顎洞後壁後方，翼突窩を 検索するため骨欠損部の周囲を開空したが明らかな膿瘍 形成は認められなかった，鼻外切開を特き，眼窩内側を 検索したが，眼窩内には膿瘍形成は認めず，眼窩内側壁， 下壁に打いて子骨破壊は久られなかった。黒褐色内容物 の迅速病理診断を行ったところ真菌症と診断されたため, 前，後部篩骨洞粘膜を郭清し，自然孔を広く開放した。 篩骨洞に执いては異常所見を認めなかった。

病理所見：上顎洞粘膜は高度に腫大し内腔に黒褐色の 乾酪物質を認めた。真菌検查と病理組織学検査によりア スペルギルスと診断された。採取した上䫇洞粘膜内にア スペルギルスの進入は認められなかった(図 3 ).

経過: 術後 fluconazole $100 \mathrm{mg}$ 点滴静注開始したが視 力低下著しく，2 月20日，右光覚消失となった。速効型 インスリン 10 単位，中間型インスリン 2 単位の皮下注射

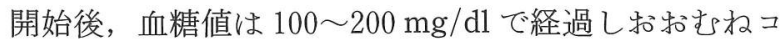
ントロール良好であった。WBC $2700 / \mu 1 ， \mathrm{CRP} 1.3$ $\mathrm{mg} / \mathrm{dl}$, と炎症所見飞消退傾向を認めたため 3 月 17 日 fluconazole を中止し itaraconazole $100 \mathrm{mg}$ 内服とした. 4 月 3 日, 血清中 $\beta$-D グルカンを測定したところ 72.4 


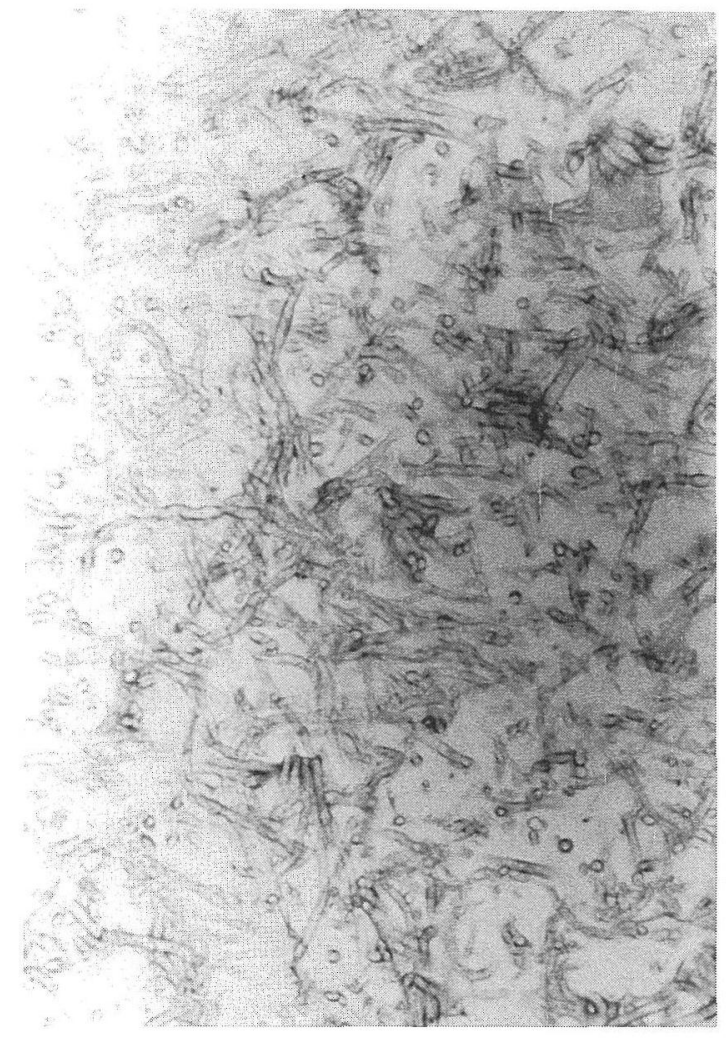

図 3 摘出物の病理組織学的所見 $(\mathrm{HE}$ 染色 $\times 400)$

$\mathrm{pg} / \mathrm{d} 1$ と高值を示したが，CRP $0.2 \mathrm{mg} / \mathrm{d} 1$ 以下と炎症反 応消失していた。しかし，5月中旬より両側側頭部痛が 出現し徐々飞意識状態悪化した．髄液検査上異常所見認 めず，また髄膜刺激症状も認められなかった，全身状態 の悪化著しく，頭部 CT, MRI 検査を行うことができず 頭蓋内合併症の確認はできなかった。 5 月26日突然の呼 吸停止のため死亡した。

\section{考察}

副鼻腔真菌症は, 比較的まれな疾患とされてきたが, 佐伯ら ${ }^{1)}$ とると近年その報告例の増加（1984１993で 152例) 認めている. 原因菌ではアスペルギルスが過半 数を占めるとされている.

アスペルギルスによる副鼻腔真菌症は，骨破壞を伴い， 眼窩内, 頭蓋内合併症を引き起こし悪性腫瘍に類似した 症状を呈する破壊型と骨破壊执よびその随伴症状を欠き 上顎洞洗浄時あるいは副鼻腔根治術施行時に偶然発見さ れる寄生型に分類される5)が，本邦に扣いては後者が圧 倒的に多く, 我々の渉猟し得た範囲では破壊型は16例の
報告をみるにすぎず，極めてまれであるとい光る。

今回経験した症例は invasive type と考光られ, 上顎 洞後壁を破壊した後, 翼口蓋窩から眼窝先端部に炎症が 波及したと考兄られる。invasive type にみられる骨破 壊の機序としては, 糖尿病を背景に, (1)血管内に進入し た真菌による血管閉塞 (循環障害) ${ }^{6)}$ と(2)アフラトキシン をはじめとした菌体毒素による凝固壞死》の 2 つが考克 られた。

市村8) や真崎9) そよると副鼻腔真菌症の成因として， 洞内の嫌気的な環境が密接に関与寸るとされているが, 本症例の上らに糖尿病を合併する場合, 末梢循環障害を 来し，その結果洞内を嫌気的環境導くことが考学られ， リスクファクターの 1 つ考光られる。また, 真菌は active ketone reductase system を有するため, 糖が多 く, 且つ酸性の条件下に生存しやすいとされている。ケ トアシドーシスに执いて単球系の貪食能が低下し, 炎症 反応が遷延化することも糖尿病と副鼻腔真菌症の密接な 関係を裏付けるものと考光られる。

アスペルギルスは血管親和性があり, 内弾性板を侵し 血管壁を穿通して血行性に散布し，転移巣を形成したり， 血栓形成や組織の梗塞, 壊死を生じやすく, このため頭 蓋内進展による死亡例が多いとされている310111)。本症 例に括いては側頭部痛, 意識障害を認めている。CT 検 查, 髄液検查を施行していないため断定できないが頭蓋 内への直接浸潤もしくは動脈管内での塞栓形成による脳 梗塞を併発した可能性があると思われる。

一般的に真菌症に执いて神経症状を認める場合, 䯣液 所見や培養は必須であるとされる，好中球増加やタンパ クの増加と糖の減少は真菌性髄膜炎を示唆するものであ り, 加光て主要血管への浸潤，閉塞が疑われるときには 血管造影や CT 検査が有用であるとされる。しかし本症 例のように全身状態が悪く十分な検査がでさないことも 多い。

鑑別診断としては萎縮性鼻炎，進行性鼻壊症，正中悪 性細網症, 敗血症性海綿静脈洞血栓症, 激症細菌感染, 梅毒, 結核, 上顎癌をはじめとする上顎腫瘍, 慢性副鼻 腔炎, 歯性上顎洞炎, カンジダ症, ムコール症などの他 の真菌症, 他の慢性肉芽腫性疾患, 脳腫瘍, 上咽頭腫瘍 などがあげられる。

確定診断は菌の証明であり, 西岡ら ${ }^{12)}$ による上顎 洞穿刺洗浄液の遠沈鏡検による検査，おっよびこの培養に よる術前細胞学的診断法が有力な検査, 診断法とされて 
いる. 犬山ら ${ }^{13)}$ とよると上顩洞真菌症の CT 所見の特 徵として上靧洞内は通常の慢性副鼻腔炎に比べやや陰影 の濃淡があり均一さにかけるとされている，われわれの 症例でも上顎洞内側壁, 前壁, 後壁に強い陰影を認め, 水平断では陰影飞濃淡のある均一さに欠ける像が認めら れた。これらの所見は片側性の骨肥厚とともに上顎洞真 菌症の CT 所見の特徵を呈して掠り補助診断として有効 であると考えられた。

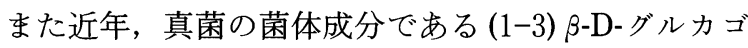
ン(以下 $\beta$-D-グルカゴン)の測定が深在性真菌症の診断 に括いて有效であるとされている(14) 17). 光武ら ${ }^{14)}$ によ るとアスペルギルス症の臨床的な活動性を定量的に示す とされており，有効な診断法と考えられる.

その他の診断方法として中村ら ${ }^{18)}$ は PCR 法による asuperugillus DNA の検出法を極めて高感度であると報告 している.

治療として寄生型は手術による病巣摘出によりほとん ど制御されているが，破壊型に対しては現在のところ治 療法は確立されていない. Hora ${ }^{5)}$ は手術による病巣の 徹底的除去と抗真菌剤の投与に頼らざるを得ないとして いる．抗真菌剤としては Amphotericin B が第 1 選択と されているが，本症例に执いては，血中BUN $29 \mathrm{mg} /$ $\mathrm{d} 1$ と腎機能低下が示唆されたため腎障害の少ない fluconazole を用いた．森ら ${ }^{19)}$ とると腎不全状態の患者 に括いても重大な副作用がないと報告されて抮り, 腎障 害を認める患者に执いては有効であると思われる，本症 例に执いては fluconazole 投与後, 明らかな腎障害は認 められなかった。

今回, 我々は上䫇洞内の病巣は可及的に除去し, 術後, 抗真菌剤を投与したにもかかわらず不幸な転帰をとった 破壊型の上铞洞アスペルギルス症の 1 例を経験した. 今 後破壊型の副鼻腔アスペルギルス症に掓る早期診断方 法扣よび有効な治療法の確立が望まれる.

\section{参考文献}

1) 佐伯忠彦, 竹田一彦, 白馬伸洋 : 副鼻腔真菌症の臨床的検 討. 耳鼻臨床 $89 ： 199 \sim 207,1996$.

2 ）笠井郁雄, 大西 真, 堀野一人, 他: 悪性腫瘍を疑った, 骨破壊を伴った上顎洞アスペルギルス症の一例. 日口外誌 $41:$ 1089 1091, 1995.

3 ）植田広海, 伊藤明和, 柳田則之 : 不幸な転機をとった上䫇
洞真菌症. 耳喉 $58: 257 \sim 261,1986$.

4 ) 西平茂樹, 井谷 修, 戸川 清 : 眼症状を呈した副鼻腔ア スペルギルス症の 1 例. 耳喉 $57:$ 499 504, 1985.

5 ) Hora JF : Primary aspergillosis of the paranasal sinuses and assosiated areas. Laryngoscope $75: 768 \sim 773,1965$.

6 ) Smith HW, Kirchner JA and Conn NH : Cerebral mucormycosis. Arch Otolaryngol $68: 715 \sim 726,1958$.

7 ）網谷良一, 田中栄作, 村山尚子, 他: アスペルギルスから 産生されるマイコトキシン, プロテアーゼ. 呼吸 $14: 923$ 〜931, 1995.

8 ）市村恵一：鼻副鼻腔真菌症と眼症状 一自験例13例と国内 外報告例からみた眼合併症の成立機序について一. 耳喉 $54: 57 \sim 63,1982$.

9 ）真崎正美 : 副鼻腔アスペルギルス症 一自験例11症例及び 本邦報告例からの検討一. 耳展 $25: 138 \sim 143,1982$.

10) Weidenbacher $M$ and Brandt $G:$ Lethal aspergillosis of the paranasal sinuses. Laryngol Rhinol Otol $54: 722 \sim 727$, 1975.

11）渡辺一功：アスペルギルス属. 化学療法の領域 3:375〜 379, 1987.

12）西岡慶子, 小河原利彰, 内藤正之, 他 : 上顎洞アスペルギ ルス症の術前細胞学的診断. 耳喉 $56: 99 \sim 104,1984$.

13）犬山征夫, 小津電助, 堀内正敏, 他 : 副鼻腔真菌症に関す る臨床的観察. 耳鼻臨床 $69: 325 \sim 335,1976$.

14）光武耕太郎, 宮崎幸重, 宮崎治子, 他：アスペルギルス括 よびクリプトコッカス呼吸器 一感染症での血中 $\beta$-D-グル カンの測定一. 日胸疾会誌 $32: 37 \sim 41,1994$.

15）瀬賀弘行, 石塚 修, 塚田弘樹, 他： $\beta$-D-グルカンと深在 性カンジダ症. 日化療会誌 $43: 265,1995$.

16）宮崎幸重, 河野 茂, 光武耕太郎, 他 : 真菌多糖類による リムステスト (factor G) 活性化について. 感染症誌 66 : 1030, 1992

17) Dupont B, Hurbor M, Kim SJ , et al : Galactomannan antigenemia and antigenuria in asuperugillosis ; studies on patients and experimentally infected rabbits. J Infect Dis $155: 1,1987$.

18）中村秀範, 柴田陽光, 工藤幸晴, 他 : PCR 法によるアス ペルギルス症の DNA 診断. 臨床病理 42 : 676 681, 1994.

19）森 健, 松村万喜子, 江部 司, 他：Fluconazole に上る 深在性真菌症の治療. Jap J Antibiotics $42: 55 \sim 61,1989$.

$$
\left.\begin{array}{l}
\text { 原稿受付 : 平成 } 10 \text { 年 } 1 \text { 月 } 5 \text { 日 } \\
\text { 原稿採択 : 平成 } 10 \text { 年 } 3 \text { 月 } 31 \text { 日 } \\
\text { 別刷請求先 : 石光亮太郎 } \\
\text { 厂 } 693-8501 \text { 島根県出雲市塩冶町 } 89-1 \\
\text { 島根医科大学耳鼻咽喉科学教室 }
\end{array}\right)
$$

